\title{
Protein $\mathrm{C}$ activation by an activator purified from the venom of Agkistrodon halys halys
}

Citation for published version (APA):

Bakker, H. M., Tans, G., Yukelson, L. Y., Janssen-Claessen, T. W., Bertina, R. M., Hemker, H. C., \& Rosing, J. (1993). Protein C activation by an activator purified from the venom of Agkistrodon halys halys. Blood Coagulation \& Fibrinolysis, 4, 605-614. https://doi.org/10.1097/00001721-199308000-00012

Document status and date:

Published: 01/01/1993

DOI:

10.1097/00001721-199308000-00012

Document Version:

Publisher's PDF, also known as Version of record

\section{Please check the document version of this publication:}

- A submitted manuscript is the version of the article upon submission and before peer-review. There can be important differences between the submitted version and the official published version of record. People interested in the research are advised to contact the author for the final version of the publication, or visit the DOI to the publisher's website.

- The final author version and the galley proof are versions of the publication after peer review.

- The final published version features the final layout of the paper including the volume, issue and page numbers.

Link to publication

\footnotetext{
General rights rights.

- You may freely distribute the URL identifying the publication in the public portal. please follow below link for the End User Agreement:

www.umlib.nl/taverne-license

Take down policy

If you believe that this document breaches copyright please contact us at:

repository@maastrichtuniversity.nl

providing details and we will investigate your claim.
}

Copyright and moral rights for the publications made accessible in the public portal are retained by the authors and/or other copyright owners and it is a condition of accessing publications that users recognise and abide by the legal requirements associated with these

- Users may download and print one copy of any publication from the public portal for the purpose of private study or research.

- You may not further distribute the material or use it for any profit-making activity or commercial gain

If the publication is distributed under the terms of Article $25 \mathrm{fa}$ of the Dutch Copyright Act, indicated by the "Taverne" license above, 


\title{
Protein $\mathrm{C}$ activation by an activator purified from the venom of Agkistrodon halys balys
}

\author{
H. M. Bakker, G. Tans, L. Y. Yukelson, T. W. Janssen-Claessen, \\ R. M. Bertina, H. C. Hemker and J. Rosing
}

(Received 22 April 1993; accepted in revised form 10 June 1993)

\begin{abstract}
The protein C activator from Agkistrodon balys balys venom was purified 533-fold by ion-exchange chromatography on QAE-Sephadex A-50, affinity chromatography on aprotinin-Sepharose and Mono-Q fast protein liquid chromatography. The purified enzyme is a single chain protein with an apparent molecular weight of 36000 that activates protein $\mathrm{Cby}$ proteolytic removal of a small fragment from the heavy chain. The protein $\mathrm{C}$ activator exhibited a high amidolytic activity towards the tripeptide substrates D-Pro-Phe-Arg-pNA (S2302) and D-Phe-(pipecolyl)-Arg-pNA (S2238). The activity of the activator was not affected by thiolprotease or metalloprotease inhibitors. The activator was inhibited, however, by benzamidine, Phe-Pro-Arg chloromethyl ketone, $p$-nitrophenyl $p$-guanidinobenzoate and soy bean trypsin inhibitor, which classifies the enzyme as a serine protease. The purified protease was capable of activating both human and bovine protein $\mathrm{C}$. Activation of human protein $\mathrm{C}$ only occurred at an appreciable rate in a calcium-free reaction medium at low ionic strength. $\mathrm{Ca}^{2+}$ ions inhibited the activation of human protein $\mathrm{C}$ with an apparent $\mathrm{K}_{\mathrm{i}}$ of $0.8 \mathrm{mM}$. Addition of $\mathrm{NaCl}$ to the reaction medium also strongly inhibited human protein $\mathrm{C}$ activation ( $50 \%$ inhibition at $20 \mathrm{mM} \mathrm{NaCl}$ ). Kinetic analysis of human protein $\mathrm{C}$ activation by the venom activator (in a calcium-free medium) revealed an apparent $K_{\mathrm{m}}$ for protein $\mathrm{C}$ of $0.52 \mu \mathrm{M}$ and a $k_{\mathrm{cat}}$ of $0.17 \mathrm{~s}^{-1}$ at $I=0.05\left(k_{\mathrm{cat}} / \mathrm{K}_{\mathrm{m}}=3.3 \times 10^{5} \mathrm{M}^{-1} \mathrm{~s}^{-1}\right)$. At $\mathrm{I}=0.15$ rates of human protein $\mathrm{C}$ activation became linear with protein $\mathrm{C}$ indicating a strong increase in $\mathrm{K}_{\mathrm{m}}$ with increasing ionic strength. Activation of bovine protein $\mathrm{C}$ was hardly affected by variation of $\mathrm{Ca}^{2+}$ and $\mathrm{NaCl}$ concentrations in the reaction medium. The apparent $\mathrm{K}_{\mathrm{i}} \mathrm{s}$ for calcium ion and $\mathrm{NaCl}$ inhibition of bovine protein $\mathrm{C}$ activation were $>10 \mathrm{mM}$ and $220 \mathrm{mM}$, respectively. At $\mathrm{I}=0.1$ and in the absence of $\mathrm{Ca}^{2+}$ ions bovine protein $\mathrm{C}$ was activated with a $\mathrm{K}_{\mathrm{m}}$ of $0.056 \mu \mathrm{M}$ and a $\mathrm{k}_{\mathrm{cat}}$ of $0.24 \mathrm{~s}^{-1}$ $\left(k_{\text {cat }} / \mathrm{K}_{\mathrm{m}}=4.3 \times 10^{6} \mathrm{M}^{-1} \mathrm{~s}^{-1}\right)$. Our data are indicative for a rather large conformational and/or structural difference between human and bovine protein $\mathrm{C}$ at physiological ionic strength.
\end{abstract}

Key words: Human and bovine protein C activation, Agkistrodon halys halys venom, snake venom activator.

\section{Introduction}

Protein C is a vitamin K-dependent glycoprotein that circulates in the blood as the zymogen of the serine protease, activated protein C. ${ }^{1}$ Protein $\mathrm{C}\left(\mathrm{M}_{\mathrm{r}}=62000\right)$ consists of a heavy chain $\left(M_{r}=41000\right)$ and a light chain $\left(M_{r}=21000\right)$ linked via a disulphide bridge. ${ }^{2}$ After activation protein $C$ is converted into activated protein C (APC), which is an efficient inhibitor of blood coagulation whose anticoagulant properties have been attributed to its ability to inactivate factor $\mathrm{V}^{3,4}$ and factor VIII ${ }^{5-7}$ and to promote fibrinolysis. ${ }^{8}$ In vivo protein
C activation occurs at the endothelial cell surface and is catalysed by the thrombin-thrombomodulin complex ${ }^{9}$ which in case of human protein $\mathrm{C}$ removes a dodecapeptide from the amino terminal end of the heavy chain. ${ }^{2}$

Protein $\mathrm{C}$ is also activated by trypsin, ${ }^{10}$ the factor $\mathrm{X}$ activator from Russell's viper venom ${ }^{10}$ and by proteases from the venoms of the Southern copperhead, Agkistrodon contortrix contortrix ${ }^{11-16}$ and the tropical moccasin, Agkistrodon bilineatus. ${ }^{17}$ Finally, an acti-

H. M. Bakker, G. Tans, T. W. Janssen-Claessen, H. C. Hemker and J. Rosing are with the Cardiovascular Research Institute Maastricht, University of Limburg, PO Box 616, 6200 MD Maastricht, The Netherlands. L. Y. Yukelson is with the Institute of Biochemistry, Uzbek Academy of Sciences, Tashkent, Uzbekistan and R. M. Bertina is with the Haemostasis and Thrombosis Research Centre, University Hospital, Leiden, The Netherlands. Address correspondence to J. Rosing. Tel: (+31) 43-881674; Fax: $(+31)$ 43-670988. 
the protein $\mathrm{C}$ antigen concentration by specific ELISA and using a $M_{r} 56000$.

The protein C activator present in crude Agkistrodon halys halys venom was purified as follows. $722 \mathrm{mg}$ crude venom dissolved in $35 \mathrm{ml} 25 \mathrm{mM}$ Tris/ $\mathrm{HCl}(\mathrm{pH}$ 7.5 at $\left.4^{\circ} \mathrm{C}\right), 50 \mathrm{mM} \mathrm{NaCl}, 1 \mathrm{mM}$ EDTA was applied to a QAE-Sephadex column $(2.5 \times 21 \mathrm{~cm})$ equilibrated in the same buffer and the column was washed with three column volumes $25 \mathrm{mM}$ Tris $/ \mathrm{HCl}\left(\mathrm{pH} 7.5\right.$ at $\left.4^{\circ} \mathrm{C}\right), 100$ $\mathrm{mM} \mathrm{NaCl}, 1 \mathrm{mMEDTA}$. Venom proteins that adhered to the column were eluted with a linear salt gradient of $2 \times 250 \mathrm{ml}$ from 100 to $500 \mathrm{mM} \mathrm{NaCl}$. Column fractions were tested for the presence of a protein $\mathrm{C}$ activator as described below. The activator adhered to the column and eluted in the gradient at about $200 \mathrm{mM}$ $\mathrm{NaCl}$. Fractions containing the protein $\mathrm{C}$ activator were pooled and dialysed against $20 \mathrm{mM}$ hydroxyethylpiperazine ethanesulphonic acid (HEPES) ( $\mathrm{pH} 7.5$ ) and subsequently applied to an aprotinin-Sepharose column (35 mg aprotinin coupled to $10 \mathrm{ml} \mathrm{CNBr-}$ Sepharose according to the manufacturer's instructions). The protein $\mathrm{C}$ activator bound to the aprotininSepharose column which was then washed with five column volumes $20 \mathrm{mM}$ HEPES ( $\mathrm{pH} 7.5$ ), $50 \mathrm{mM}$ $\mathrm{NaCl}$ and developed with a linear salt gradient $(2 \times 40$ $\mathrm{ml}$ ) of $50-300 \mathrm{mM} \mathrm{NaCl}$ in the same buffer. The activator eluted at about $125 \mathrm{mM} \mathrm{NaCl}$. The fractions containing protein $\mathrm{C}$ activator were pooled, dialysed against $25 \mathrm{mM}$ Tris ( $\mathrm{pH} 7.5$ at room temperature), 50 $\mathrm{mM} \mathrm{NaCl}, 1 \mathrm{mM}$ EDTA and subjected to ionexchange chromatography on a Mono-Q column connected to an FPLC-system of Pharmacia. The activator adhered to the column and was eluted with a linear salt gradient of $50-300 \mathrm{mM} \mathrm{NaCl}$. To remove the final contaminants the fractions containing activator were pooled, dialysed against $25 \mathrm{mM}$ Tris ( $\mathrm{pH} 7.5$ at room temperature), $50 \mathrm{mM} \mathrm{NaCl}, 1 \mathrm{mM}$ EDTA and rechromatographed on Mono-Q. The column was washed with 10 column volumes start buffer and developed with a linear gradient of $50-150 \mathrm{mM} \mathrm{NaCl}$ ( $5 \mathrm{ml}$ total volume). Elution with $150 \mathrm{mM} \mathrm{NaCl}$ containing buffer was continued during which the activator eluted as a single peak.

\section{Protein Cactivation}

During the purification of the Agkistrodon halys halys activator protein $C$ activation was routinely determined as follows. $40 \mu \mathrm{l}$ column fraction, appropriately diluted in $20 \mathrm{mM}$ HEPES ( $\mathrm{pH} 7.5$ ), $1 \mathrm{mM}$ EDTA, 0.5 $\mathrm{mg} / \mathrm{ml}$ ovalbumin, was preincubated at $37^{\circ} \mathrm{C}$ for $5 \mathrm{~min}$ and protein $\mathrm{C}$ activation was started by adding $10 \mu \mathrm{l}$ of $1 \mu \mathrm{M}$ bovine protein $\mathrm{C}$ (prewarmed) in the same buffer. After an additional 5 min a $25 \mu$ laliquot of the activation mixture was transferred to a cuvette with
$475 \mu$ l of a buffer containing $50 \mathrm{mM}$ Tris ( $\mathrm{pH} 7.9$ at room temperature), $175 \mathrm{mM} \mathrm{NaCl}, 20 \mathrm{mM}$ EDTA, 0.5 $\mathrm{mg} / \mathrm{ml}$ ovalbumin and $192 \mu \mathrm{M}$ S2366. From the $\Delta \mathrm{A}_{405-500 \mathrm{~nm}}$ determined on a dual wavelength spectrophotometer the amount of activated protein $\mathrm{C}$ was calculated using the kinetic parameters for S2366 conversion by bovine APC given by the manufacturer.

Initial rates of protein $C$ activation by the purified activator were determined in a total reaction volume of $250 \mu \mathrm{l}$ as follows. Varying amounts of protein $\mathrm{C}$ were preincubated for $5 \mathrm{~min}$ at $37^{\circ} \mathrm{C}$ in a reaction buffer (composition given in the legends to the figures) and protein $\mathrm{C}$ activation was started by the addition of 10 $\mu l$ of purified activator in the same buffer. Aliquots of $25 \mu \mathrm{l}$ were removed at 1,3 and $5 \mathrm{~min}$ from the reaction mixture and assayed for activated protein $\mathrm{C}$ with S2366 as described above. Quantitation of human APC was based on the kinetic parameters of S2366 conversion by human APC reported by Sala et al. ${ }^{24}$ Rates of protein C activation were linear with time and proportional to the amount of activator added and expressed in $\mathrm{nM}$ APC formed per min. Further experimental details are given in the legends to the figures.

\section{Gel electrophoresis}

Electrophoresis of proteins was carried out as described by $\mathrm{Laemmli}^{25}$ on $10 \%$ polyacrylamide gels ( $6 \%$ stacking gel) in the presence of SDS. After electrophoresis the gels were stained for protein with $\mathrm{Coo}-$ massie Brilliant Blue R250. Zymographic detection of the protein $\mathrm{C}$ activator was carried out using the amidoblot procedure described earlier. ${ }^{26}$ To this end the activator was transblotted on to nitrocellulose and SDS was removed by soaking the nitrocellulose sheet for $3 \mathrm{~h}$ at room temperature in $25 \mathrm{mM}$ Tris (pH 7.9), $90 \mathrm{mM}$ $\mathrm{NaCl}$ containing $2.5 \%$ Triton $\mathrm{X}-100$ followed by four washes (7.5 min) in $25 \mathrm{mM}$ Tris (pH 7.9). The nitrocellulose sheet was subsequently placed on an agarose gel of $1.25 \%$ agarose in $25 \mathrm{mM}$ Tris ( $\mathrm{pH} 7.9$ ), $1 \mathrm{mM}$ EDTA, $480 \mu \mathrm{M}$ S2366 and $0.5 \mu \mathrm{M}$ bovine protein C. If there is protein $\mathrm{C}$ activator present on the nitrocellulose sheet APC is formed which liberates $p$-nitroaniline from the chromogenic substrate in the agarose and generates a yellow band on the nitrocellulose sheet. This band can be photographed by transillumination with UV-A light to achieve optimal contrast.

\section{Results}

Purification of the protein C activator from

Agkistrodon halys halys venom

The protein $\mathrm{C}$ activator was purified from the crude venom by a combination of standard chromatographic techniques involving ion-exchange chromatography 


\section{H. M. Bakker et al.}

Table 1. Purification of a protein $\mathrm{C}$ activator from the venom of Agkistrodon balys halys

\begin{tabular}{lcccc}
\hline & $\begin{array}{c}\text { Protein } \\
(\mathrm{mg})\end{array}$ & $\begin{array}{c}\text { Specific } \\
\text { activity } \\
\text { nmole APC/min/mg }\end{array}$ & $\begin{array}{c}\text { Yield } \\
(\%)\end{array}$ & $\begin{array}{c}\text { Purifi- } \\
\text { cation } \\
\text { (-fold) }\end{array}$ \\
\hline Crude venom & 722 & 0.6 & 100 & 1 \\
QAE-Sephadex & 41 & 3.5 & 33 & 5.8 \\
Aprotinin- & 11.4 & 12.0 & 31 & 20 \\
$\quad$ Sepharose & 0.9 & 98 & 20 & 163 \\
Mono-Q 1 & 0.17 & 320 & 13 & 533 \\
Mono-Q2 & & & & \\
\hline
\end{tabular}

2 Protein concentrations were calculated from the absorbance at 280 $\mathrm{nm}$ assuming $\mathrm{A}_{280}{ }^{1 \%}=10$. Further details are described under Materials and methods and in the text.

on QAE-Sephadex, affinity chromatography on aprotinin-Sepharose and repeated ion-exchange chromatography on a Mono-Q column connected to a Pharmacia FPLC system. Table 1 summarizes the purification procedure (details are given under Materials and methods) which resulted in 533-fold purification at a $13 \%$ overall yield.

Figure 1A shows a non-reduced SDS-polyacrylamide gel of the crude venom (lane 1), the purified activator (lane 2) and protein standards (lane 3). The purified activator appeared homogeneous and pure $(>95 \%)$ and migrated as a single band with an estimated $\mathrm{M}_{\mathrm{r}}$ of 36000 . SDS-PAGE of reduced samples also showed a single band at $36000 \mathrm{M}_{\mathrm{r}}$ indicating that the activator is a single chain protein (not shown).

The protein C activator on the gel was also identified by a modification of the amidoblot procedure described by Tans et al. ${ }^{26}$ The purified protein $\mathrm{C}$ activator was subjected to SDS-PAGE and transblotted on to nitrocellulose. The nitrocellulose sheet was washed and subsequently placed on a layer of agarose containing protein $\mathrm{C}$ and the protein $\mathrm{C}$-specific chromogenic substrate S2366 (Figure 1B). The appearance of a yellow band (i.e. paranitroaniline production from S2366 by APC generated in the agarose) at the migrating distance of the protein band (lane 2 Figure $1 \mathrm{~A}$ ) indicates that the protein visible on the Coomassie blue stained gel and the protein $\mathrm{C}$ activator are one and the same protein. In this respect it should be mentioned that the appearance of the yellow band was not due to direct conversion of $\$ 2366$ by the purified venom protein since omission of protein $C$ from the agarose resulted in a complete loss of $p$-nitroaniline formation (data not shown).

The product of protein $C$ activation by the protein $C$ activator

Human protein $\mathrm{C}$ is a protein with a molecular weight of 62000 that consists of a heavy chain $\left(M_{r} 41000\right)$

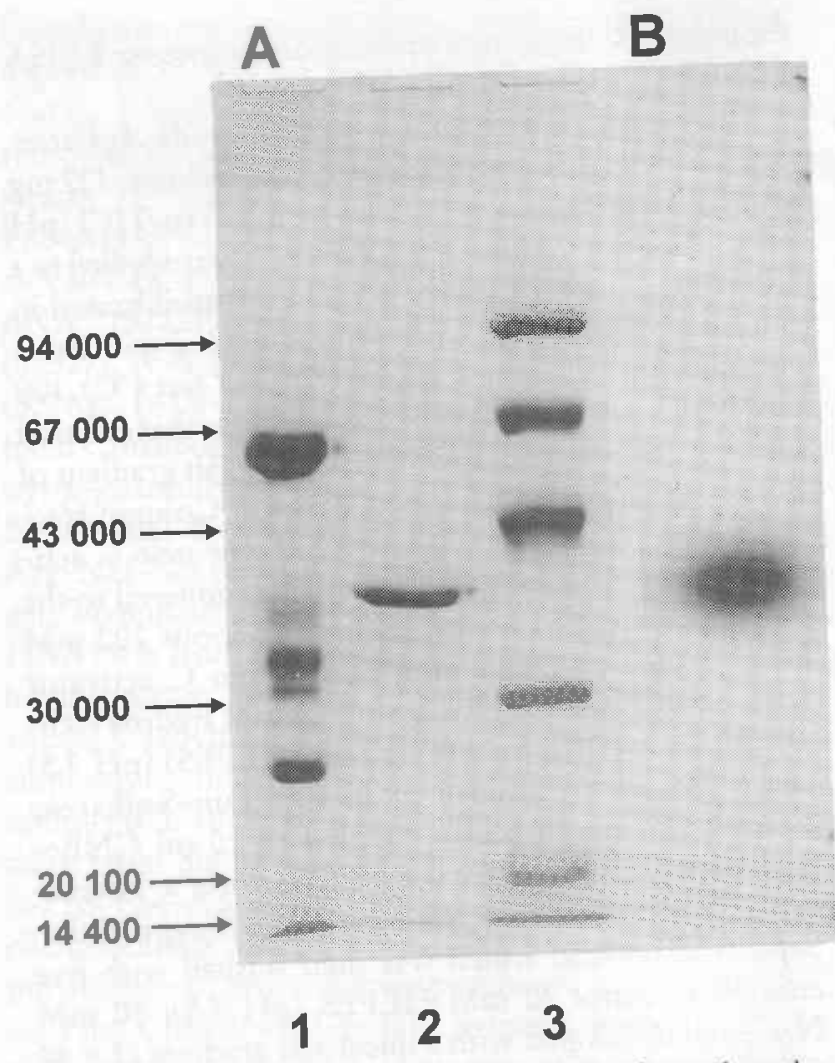

Figure 1. SDS-PAGE analysis of the protein $\mathrm{C}$ activator from the venom of Agkistrodon halys balys. Crude Agkistrodon balys balys venom and purified activator were subjected to SDS-PAGE on $10 \%$ slabgels ( $6 \%$ stacking gel) according to Laemmli ${ }^{25}$ under non-reducing conditions. (A): Gel stained with Coomassie Brilliant Blue R250. Lane 1, $13 \mu \mathrm{g}$ crude venom; Lane 2, $4 \mu \mathrm{g}$ purified activator; Lane 3, molecular weight standards. (B): After electrophoresis a separate part of the gel containing a lane with $4 \mu \mathrm{g}$ purified activator was subjected to electrophoretic transfer of the protein on to nitrocellulose and visualization of the protein C activator with protein C and S2366 as described in Materials and methods.

linked via a disulphide bridge to a light chain ( $\mathrm{M}_{\text {s }}$ 21000 ). Activation of human protein $C$ results from a specific cleavage in the heavy chain of the molecule., 2,13,17 In the case of protein $\mathrm{C}$ activation by its physiological activator, thrombin this cleavage has been identified to result in the removal of a dodecapeptide of $M_{r}=1400$ from the aminoterminus of the heavy chain. ${ }^{2}$

Figure 2 shows that the protein $\mathrm{C}$ activator purified from Agkistrodon halys halys venom probably activates human protein $\mathrm{C}$ via the same pathway. Activation of protein $C$ by our activator was accompanied by the cleavage of a small polypeptide from the heavy chain of protein $\mathrm{C}$ as indicated by the small increase in electrophoretic mobility of the heavy chain of protein $\mathrm{C}$ after complete activation. For comparison we have also electrophoresed the product of protein $\mathrm{C}$ activation by the activator from Agkistrodon contortrix 


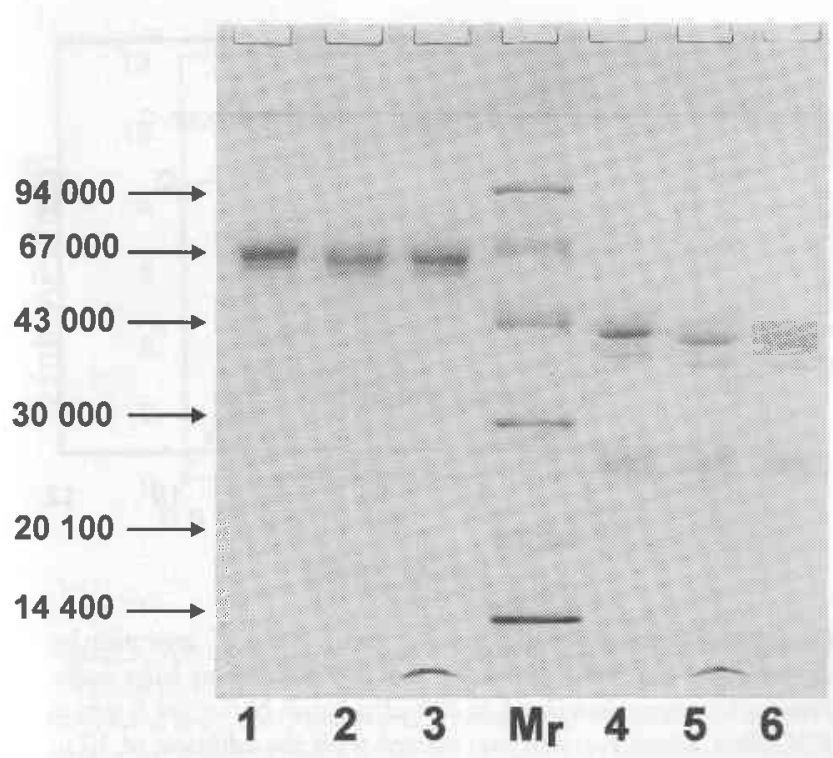

Figure 2. SDS-PAGE of protein $\mathrm{C}$ activated by the activators from the venoms of Agkistrodon halys halys and Agkistrodon contortrix contortrix. Human protein C $(16 \mu \mathrm{g})$ was activated in $100 \mu \mathrm{l}$ of a reaction buffer containing $50 \mathrm{mM}$ Tris/ $\mathrm{HCl}(\mathrm{pH} 7.9$ at room temperature), $0.5 \mathrm{mM}$ EDTA and $0.08 \mu \mathrm{g}$ of the purified activator from Agkistrodon halys halys or $0.12 \mu \mathrm{g}$ Protac (partially purified activator from Agkistrodon contortrix contortrix). After complete reaction $20 \mu \mathrm{l}$ aliquots were taken and subjected to SDS-PAGE both under non-reduced (lanes 1-3) and under reduced (lanes 4-6) conditions. A lane with molecular weight standards (identified as $\mathbf{M}_{r}$ ) was included on the gel. After electrophoresis the gel was stained with Coomassie Brilliant Blue R250. Lanes 1 and 4, protein C, Lanes 2 and 5 , protein $C$ activated with activator purified from the venom of Agkistrodon balys halys; Lane 3 and 6, protein $\mathrm{C}$ activated with Protac, the activator from Agkistrodon contortrix contortrix.

contortrix, which appeared to be indistinguishable from the APC generated by the activator from Agkistrodon balys halys. It is, therefore, highly probable that activation of protein $\mathrm{C}$ by the activators from both Agkistrodon species is due to removal of the same dodecapeptide that is also removed by thrombin. ${ }^{2}$

\section{Chromogenic substrate conversion by the protein $C$ activator}

The purified protein $C$ activator from the venom of Agkistrodon halys balys possesses amidolytic activity towards a number of commercially available synthetic peptide substrates (Table 2). High activities were observed on the kallikrein substrate $\mathrm{S} 2302$ and on the thrombin substrate S2238, whereas other substrates tested were converted at considerably lower rates. In Table 2 we have also included the rates of substrate conversion by the crude venom. From the fact that there was a considerable difference between the substrate specificities of the purified activator and the crude venom it can be concluded that the crude venom
Table 2. Amidolytic activities of crude Agkistrodon balys balys venom and of the purified protein $\mathrm{C}$ activator

\begin{tabular}{lcc}
\hline \multirow{2}{*}{ Substrate } & \multicolumn{2}{c}{ Rate of substrate hydrolysis } \\
\cline { 2 - 3 } & $\begin{array}{c}\text { Crude venom } \\
(\mu \mathrm{M} \text { pNA/min } / \mathrm{mg})\end{array}$ & $\begin{array}{c}\text { Purified activator } \\
(\mu \mathrm{M} \text { pNA/min } / \mathrm{mg})\end{array}$ \\
\hline S2238 & 0.371 & 0.703 \\
Chromozym TH & 0.346 & 0.062 \\
S2222 & 0.036 & 0.029 \\
S2337 & 0.051 & 0.009 \\
S2765 & 0.039 & 0.011 \\
S2366 & 0.129 & 0.027 \\
S2302 & 4.024 & 1.290 \\
S2288 & 0.271 & 0.048 \\
S2251 & 0.286 & 0.043 \\
\hline
\end{tabular}

Amidolytic activities were determined at $37^{\circ} \mathrm{C}$ in $1 \mathrm{ml}$ cuvettes $(1 \mathrm{~cm}$ pathlength) on an Aminco DW2-C spectrophotometer set in the dual wavelength mode at 405 minus $500 \mathrm{~nm}$. Final reaction conditions were: $50 \mathrm{mM}$ Tris/ $\mathrm{HCl}$ ( $\mathrm{pH} 7.9$ at room temp), $175 \mathrm{mM}$ $\mathrm{NaCl}, 20 \mathrm{mM}$ EDTA, $0.5 \mathrm{mg} / \mathrm{ml}$ ovalbumin, $192 \mu \mathrm{M}$ chromogenic substrate and appropriate amounts of crude venom or purified activator. From the $\Delta \mathrm{A} 405-500 / \mathrm{min}$ the rate of $p$-nitroaniline formation was calculated using a molar extinction coefficient of $9900 \mathrm{~cm}^{-1} .29$

from Agkistrodon balys balys contains other enzymes with amidolytic activity. Since the crude venom contains less than $0.2 \%$ protein $C$ activator (as can be concluded from the 533-fold purification of the activator, Table 1) it can be calculated that the protein $\mathrm{C}$ activator has a negligible contribution to the amidolytic activity of the crude venom.

\section{The effect of protease inhibitors on the activity of the protein $C$ activator}

Table 3 summarizes the effects of inhibitors of different classes of proteolytic enzymes on the activity of the protein $\mathrm{C}$ activator from Agkistrodon halys halys. Inhibitors of metallo- and thiol proteases did not affect the amidolytic activity of the protein $\mathrm{C}$ activator as determined with S2302. Considerable inhibition was observed when the protein $C$ activator was incubated with the serine protease inhibitors benzamidin, soybean trypsin inhibitor, PPACK and $p-N P G B$. The virtually complete inhibition by PNPGB and PPACK suggests that the protein $\mathrm{C}$ activator from Agkistrodon halys halys is a serine protease in which both histidine and serine residues are involved in the catalytic mechanism.

\section{Effect of $\mathrm{CaCl}_{2}$ and $\mathrm{NaCl}$ on protein $\mathrm{C}$ activation}

During our studies it became clear that the activator isolated from the venom of Agkistrodon halys balys activated both bovine and human protein $\mathrm{C}$. In this respect it resembles the protein $\mathrm{C}$ activator from the venom of Agkistrodon contortrix contortrix. Our pro- 
Table 3. Inhibition of the purified Agkistrodon halys halys activator by protease inhibitors

\begin{tabular}{lcc}
\hline Inhibitor & & $\%$ activity \\
\hline none & $(4 \mathrm{mM})$ & 100 \\
$o$-phenantrolin & $(10 \mathrm{mM})$ & 94 \\
EDTA & $(1 \mathrm{mM})$ & 107 \\
2-iodoacetamide & $(1 \mathrm{mM})$ & 99 \\
$n$-ethylmaleimide & $(100 \mu \mathrm{M})$ & 97 \\
$p$-amidino PMSF & $(60 \mathrm{nM})$ & 98 \\
antithrombin III & $(10 \mathrm{mM})$ & 117 \\
benzamidin & $(300 \mu \mathrm{M})$ & 48 \\
soybean trypsin inhibitor $(10 \mathrm{mg} / \mathrm{ml}$ & 66 \\
$p$-NPGB & $(50 \mu \mathrm{M})$ & 6 \\
PPACK & & 4 \\
\hline
\end{tabular}

$0.77 \mu \mathrm{g}$ Protein $\mathrm{C}$ activator purified from Agkistrodon halys halys venom was incubated for $1 \mathrm{~h}$ at $37^{\circ} \mathrm{C}$ in $450 \mu \mathrm{l}$ buffer containing 50 $\mathrm{mM}$ Tris $/ \mathrm{HCl}(\mathrm{pH} 7.9$ at room temperature), $175 \mathrm{mM} \mathrm{NaCl}, 0.5$ $\mathrm{mg} / \mathrm{ml}$ ovalbumin and inhibitor as indicated. The residual amidolytic activity was determined after $1 \mathrm{~h}$ by adding $50 \mu \mathrm{l} 3.84 \mathrm{mM}$ S2302 in water. The reaction with chromogenic substrate was allowed to proceed (usually between 5 and $25 \mathrm{~min}$ ) until sufficient $p$-nitroanilide was formed for accurate measurement of the absorbance at 405-500 $\mathrm{nm}$ after which $300 \mu \mathrm{l} 1 \mathrm{M}$ citric acid was added to stop $p$-nitroaniline formation. From the measured absorbance the amidolytic activity was calculated as $\Delta \mathrm{A}_{405-500} \mathrm{~nm} / \mathrm{min}$. The percentage remaining activity was obtained by taking the activity measured in the absence of inhibitors as $100 \%$.

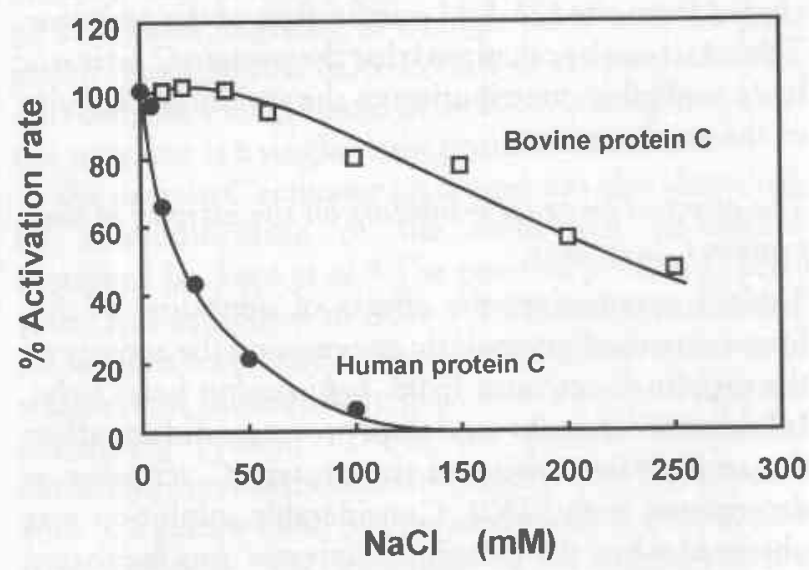

Figure 3. Effect of $\mathrm{NaCl}$ on the rate of protein $\mathrm{C}$ activation by the purified activator from Agkistrodon balys halys venom. Protein $\mathrm{C}$ was preincubated in $240 \mu \mathrm{l}$ reaction buffer for $5 \mathrm{~min}$ at $37^{\circ} \mathrm{C}$ after which reaction was started with the addition of $10 \mu l$ buffer containing purified Agkistrodon halys halys activator. Final concentrations of reactants were: $50 \mathrm{mM}$ Tris $/ \mathrm{HCl}(\mathrm{pH} 7.9$ at room temperature), $\mathrm{NaCl}$ as indicated in the figure, $5 \mathrm{mM} \mathrm{EDTA}, 0.5 \mathrm{mg} / \mathrm{ml}$ ovalbumin, $130 \mathrm{nM}$ human protein $\mathrm{C}$ and $25 \mathrm{ng}$ purified activator $(\longrightarrow)$ or 150 $\mathrm{nM}$ bovine protein $\mathrm{C}$ and $5 \mathrm{ng}$ activator $(\square-\square)$. After 1,3 and $5 \mathrm{~min}$ $25 \mu \mathrm{l}$ aliquots were removed from the reaction mixture and assayed for activated protein $C$ using the chromogenic substrate S2366 as described under Methods. From the amounts of activated protein $C$ thus determined the initial rate of protein $\mathrm{C}$ activation was calculated. The rate of protein $\mathrm{C}$ activation determined in the absence of $\mathrm{NaCl}$ was taken as $100 \%(5.9 \mathrm{nM}$ human APC formed per min and $5.4 \mathrm{nM}$ bovine APC formed per $\mathrm{min}$ ).

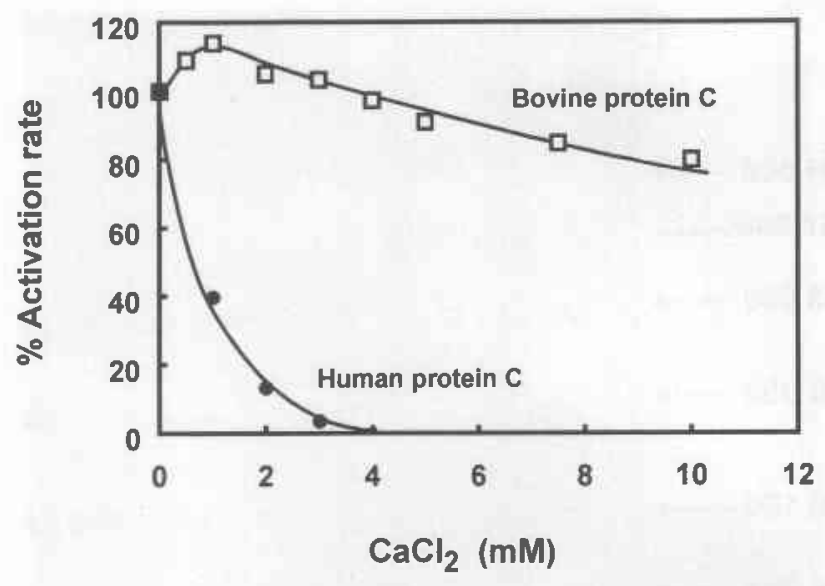

Figure 4. The effect of $\mathrm{CaCl}_{2}$ on the rate of protein $\mathrm{C}$ activation by the activator purified from the venom of Agkistrodon halys balys. Protein $\mathrm{C}$ was preincubated in $240 \mu \mathrm{l}$ reaction buffer for $5 \mathrm{~min}$ at $37^{\circ} \mathrm{C}$ after which reaction was started with the addition of $10 \mu \mathrm{l}$ buffer containing purified Agkistrodon halys balys activator. Final concentrations of reactants were: $50 \mathrm{mM}$ Tris $/ \mathrm{HCl}(\mathrm{pH} 7.9$ at room temperature), $10 \mathrm{mM} \mathrm{NaCl}, 0.5 \mathrm{mM}$ EDTA, $0.5 \mathrm{mg} / \mathrm{ml}$ ovalbumin, $130 \mathrm{nM}$ human protein $\mathrm{C}$ with $25 \mathrm{ng}$ activator $(\bullet)$ ) or $150 \mathrm{nM}$ bovine protein $\mathrm{C}$ with $4 \mathrm{ng}$ activator $(\square-\square)$ and amounts of $\mathrm{CaCl}_{2}$ in excess over EDTA to obtain the concentrations indicated in the figure. After 1, 3 and $5 \mathrm{~min} 25 \mu$ l aliquots were removed from the reaction mixture and assayed for activated protein $\mathrm{C}$ using the chromogenic substrate $\mathrm{S} 2366$ as described under Methods. From the amounts of activated protein $\mathrm{C}$ present the initial (steady-state) rate of protein $\mathrm{C}$ activation was calculated and expressed as percentage of the rate determined in the absence of added $\mathrm{CaCl}_{2}(5.7 \mathrm{nM}$ human $\mathrm{APC}$ formed per min and $4.2 \mathrm{nM}$ bovine APC formed per min).

tein $C$ activator differs, however, in one important aspect from the latter activator. Activation of both bovine and human protein $\mathrm{C}$ by the activator from Agkistrodon contortrix contortrix is strongly inhibited by $\mathrm{Ca}^{2+}$ ions ${ }^{14,15}$ and (at least for human protein $\mathrm{C}$ ) by $\mathrm{NaCl}{ }^{15}$ When we tested protein $\mathrm{C}$ activation with Protac (the activator from Agkistrodon contortrix contortrix venom) under our experimental conditions, both bovine and human protein $\mathrm{C}$ activation by Protac were strongly inhibited by $\mathrm{CaCl}_{2}\left(\mathrm{~K}_{\mathrm{i} \text { app }}<1 \mathrm{mM}\right)$ and by $\mathrm{NaCl}\left(\mathrm{K}_{\mathrm{ipp}} \approx 50 \mathrm{mM}\right)$ (data not shown). However, $\mathrm{Ca}^{2+}$ ions and increasing ionic strength had different effects on the activation of bovine and human protein $\mathrm{C}$ by the Agkistrodon halys balys protein $\mathrm{C}$ activator. Figure 3 shows that activation of human protein $C$ by the activator from Agkistrodon balys balys was strongly inhibited at increasing $\mathrm{NaCl}$ concentrations $\left(\mathrm{K}_{\mathrm{i} \text { app }}=20 \mathrm{mM}\right)$ whereas the activation of bovine protein $\mathrm{C}$ was inhibited at much higher $\mathrm{NaCl}$ concentrations $\left(\mathrm{K}_{\mathrm{i}}\right.$ app $\left.=220 \mathrm{mM}\right)$. A similar difference between bovine and human protein $\mathrm{C}$ activation was also observed when the effect of $\mathrm{Ca}^{2+}$ ions was studied (Figure 4). Activation of human protein $\mathrm{C}$ was already 

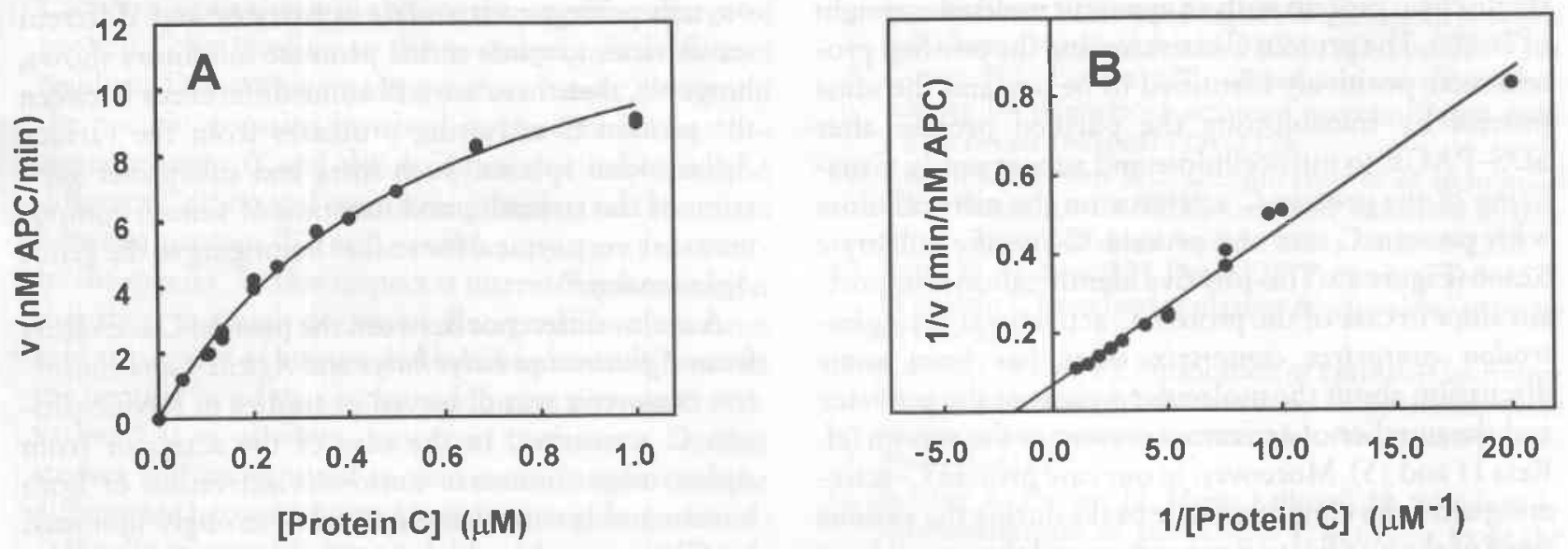

Figure 5. Kinetic analysis of human protein $\mathrm{C}$ activation by the activator purified from the venom of Agkistrodon balys halys. Varying amounts of human protein $\mathrm{C}$ were incubated for $5 \mathrm{~min}$ at $37^{\circ} \mathrm{C}$ in $140 \mu \mathrm{l}$ buffer after which reaction was started by addition of $10 \mu \mathrm{l}$ purified $\mathrm{Agkistrodon}$ halys balys activator. Final reaction conditions were: $50 \mathrm{mM} \mathrm{Tris} / \mathrm{HCl}(\mathrm{pH} 7.9$ at room temperature), $0.5 \mathrm{mM} \mathrm{EDTA}, 1 \mathrm{mg} / \mathrm{ml} \mathrm{ovalbumin}, 7.7$ ng purified activator and amounts of protein $\mathrm{C}$ as indicated in the figure. The initial rate of protein $\mathrm{C}$ activation was determined as described in the legend to Figure 3. (A) rate of protein $\mathrm{C}$ activation as a function of the protein C concentration. (B) Lineweaver-Burk plot of the same data. Further details are given under Materials and methods.

inhibited at low $\mathrm{Ca}^{2+}$ concentrations $\left(\mathrm{K}_{\mathrm{i} \text { app }}=0.8 \mathrm{mM}\right)$, whereas bovine protein $\mathrm{C}$ activation was even slightly stimulated at this calcium concentration. At much higher $\mathrm{Ca}^{2+}$ concentrations there was some inhibition of bovine protein $\mathrm{C}$ activation by the activator from Agkistrodon halys halys. The $\mathrm{K}_{\mathrm{i} \text { app }}$ for inhibition by $\mathrm{Ca}^{2+}$ ions was, however, much higher than $10 \mathrm{mM}$.

\section{Kinetic parameters of protein $C$ activation by the}

\section{protein $C$ activator}

To assess the efficiency by which the purified Agkistrodon halys halys enzyme activated human protein $C$ we determined the kinetic parameters of protein $\mathrm{C}$ activation by measuring initial rates of activation at varying protein $\mathrm{C}$ concentrations. The reaction appeared to be saturable with respect to protein $\mathrm{C}$ (Figure $5 \mathrm{~A}$ ) and obeyed Michaelis-Menten kinetics as evidenced by the straight Lineweaver-Burk plot (Figure 5B). The latter plot yields a $V_{\max }$ of $14.2 \mathrm{nM}$ protein $C$ activated per min and $\mathrm{K}_{\mathrm{m}}$ for human protein $\mathrm{C}$ of $0.52 \mu \mathrm{M}$. From the concentration of activator present in this experiment $(0.051 \mu \mathrm{g} / \mathrm{ml})$ and the molecular weight of the activator $(36000)$ it can be calculated that the $k_{\text {cat }}$ is $0.17 \mathrm{~s}^{-1}$ and $k_{\text {cat }} / \mathrm{K}_{\mathrm{m}}=3.3 \times 10^{5} \mathrm{M}^{-1} \mathrm{~s}^{-1}$. These kinetic parameters were determined in a reaction medium that did not contain $\mathrm{NaCl}$. It was not possible to obtain kinetic parameters at high $\mathrm{NaCl}$ concentrations since we were not able to saturate the activator with human protein $\mathrm{C}$ $\left(\mathrm{K}_{\mathrm{m}}>2 \mu \mathrm{M}\right)$ and from the observed rate of APC formation the second-order rate constant $\left(k_{\mathrm{car}} / \mathrm{K}_{\mathrm{m}}\right)$ was calculated to be $4.3 \times 10^{4} \mathrm{M}^{-1} \mathrm{~s}^{-1}$ at $50 \mathrm{mM} \mathrm{NaCl}$.

The activation of bovine protein $\mathrm{C}$ has more favour- able kinetic parameters. At $50 \mathrm{mM} \mathrm{NaCl} \mathrm{a} \mathrm{V} \mathrm{max}_{\max }$ of 10.4 $\mathrm{nM} \mathrm{APC} / \mathrm{min}$ and $\mathrm{a} \mathrm{K}_{\mathrm{m}}$ of $0.056 \mu \mathrm{M}$ were obtained at $0.026 \mu \mathrm{g} / \mathrm{ml}$ activator which yields a $k_{\text {cat }}$ of $0.24 \mathrm{~s}^{-1}$ and a $k_{\mathrm{cat}} / \mathrm{K}_{\mathrm{m}}$ of $4.3 \times 10^{6} \mathrm{M}^{-1} \mathrm{~s}^{-1}$. The latter value indicates that at $50 \mathrm{mM} \mathrm{NaCl}$ bovine protein $\mathrm{C}$ is activated with a 100 -fold higher catalytic efficiency than human protein $C$. The kinetic parameters obtained in the experiments discussed above are summarized in Table 4.

\section{Discussion}

In the present paper we have described the purification and the characterization of a protein $\mathrm{C}$ activator from the venom of Agkistrodon halys halys. The activator is a

Table 4. Kinetic parameters of protein $\mathrm{C}$ activation by the activator purified from Agkistrodon halys halys venom

\begin{tabular}{lccc}
\hline Substrate & $\begin{array}{c}k_{\text {cat }} \\
\left(\mathrm{s}^{-1} \pm \mathrm{SE}\right)\end{array}$ & $\begin{array}{c}\mathrm{K}_{\mathrm{m}} \\
(\mu \mathrm{M} \pm \mathrm{SE})\end{array}$ & $\begin{array}{c}k_{\text {ca }} / \mathrm{K}_{\mathrm{m}} \\
\left(\mathrm{M}^{-1} \mathrm{~s}^{-1} \pm \mathrm{SE}\right)\end{array}$ \\
\hline $\begin{array}{l}\text { Human protein C } \\
\mathrm{I}=0.05\end{array}$ & $0.17 \pm 0.007$ & $0.52 \pm 0.04$ & $4.3( \pm 0.4) \times 10^{5}$ \\
$\mathrm{I}=0.15$ & $\mathrm{ND}$ & $\mathrm{ND}$ & $3.4( \pm 0.3) \times 10^{4}$ \\
$\begin{array}{c}\text { Bovine protein C } \\
\mathrm{I}=0.10\end{array}$ & $0.24 \pm 0.006$ & $0.056 \pm 0.004$ & $4.4( \pm 0.4) \times 10^{6}$ \\
\hline
\end{tabular}

Kinetic parameters of protein $\mathrm{C}$ activation were obtained at $37^{\circ} \mathrm{C}$ as described under Materials and methods and under the legend to Figure 5 . In the case of human protein $C$ activation at $I=0.15$ rates of $\mathrm{APC}$ formation were linear with respect to protein $\mathrm{C}$ concentration and from the observed reaction rates the second-order rate constant, which equals $k_{\mathrm{ca}} / \mathrm{K}_{\mathrm{m}}$, was calculated. Further details are given in the text. 
single chain protein with an apparent molecular weight of 36000 . The protein $\mathrm{C}$ activator and the purified protein were positively identified to be one and the same protein by transblotting the purified protein after SDS-PAGE to nitrocellulose and subsequently visualizing of the protein $\mathrm{C}$ activator on the nitrocellulose with protein $\mathrm{C}$ and the protein $\mathrm{C}$-specific substrate S2366 (Figure 1). This positive identification is important since in case of the protein C activator from $\mathrm{Agkis-}$ trodon contortrix contortrix there has been some discussion about the molecular weight of the activator and the number of activators present in the venom (cf. Refs 11 and 15). Moreover, in our case protein C-activating activities eluted in single peaks during the various steps of the purification procedure and thus we did not find evidence that Agkistrodon halys halys venom might contain more than one protein $\mathrm{C}$ activator.

The protein C activator from Agkistrodon balys balys hydrolysed several tripeptide- $p$-nitroanilide substrates and its activity was readily inhibited by $p$-NPGB and PPACK which identifies the activator as a serine protease. The activator converted both human and bovine protein C into APC by removal of a small polypeptide fragment from the heavy chain of protein C. It is very likely that protein $\mathrm{C}$ activation by the venom activators from different Agkistrodon species is the result of cleavage of the same peptide bond in protein $C$ that is also cleaved by thrombin ${ }^{2}$ yielding products with the same functional activity.

Whereas the rate of hydrolysis of tripeptide-pnitroanilide substrates by the activator was not affected by variation of the $\mathrm{Ca}^{2+}$ and $\mathrm{NaCl}$ concentrations in the reaction medium there was considerable inhibition of human protein $\mathrm{C}$ activation in activation mixtures which contained $\mathrm{Ca}^{2+}$ ions or high $\mathrm{NaCl}$ concentrations. Fifty per cent inhibition of human protein $\mathrm{C}$ activation by the venom activator was observed at 0.8 $\mathrm{mM} \mathrm{CaCl}_{2}$ and $20 \mathrm{mM} \mathrm{NaCl}$, respectively. Kinetic studies at low ionic strength $(\mathrm{I}=0.05)$ in the absence of $\mathrm{Ca}^{2+}$ ions revealed an apparent $\mathrm{K}_{\mathrm{m}}$ for human protein $\mathrm{C}$ of $0.52 \mu \mathrm{M}$ and a $k_{\text {cat }}$ of $0.17 \mathrm{~s}^{-1}$ from which a catalytic efficiency $\left(\mathrm{k}_{\mathrm{cat}} / \mathrm{K}_{\mathrm{m}}\right)$ of $3.3 \times 10^{5} \mathrm{M}^{-1} \mathrm{~s}^{-1}$ can be calculated. Increasing the ionic strength to 0.1 caused a ten-fold decrease of $k_{\mathrm{cat}} / \mathrm{K}_{\mathrm{m}}\left(4.3 \times 10^{4} \mathrm{M}^{-1} \mathrm{~s}^{-1}\right)$ which is at least partially due to an effect of ionic strength on the $\mathrm{K}_{\mathrm{m}}$ for protein $\mathrm{C}$ which becomes $>2 \mu \mathrm{M}$.

The properties discussed thus far indicate that the protein $\mathrm{C}$ activator from Agkistrodon balys halys is remarkably similar to the protein $\mathrm{C}$ activators from Agkistrodon contortrix contortrix ${ }^{13-15}$ and Agkistrodon bilineatus ${ }^{17}$ with respect to molecular weight, catalytic efficiencies of human protein $\mathrm{C}$ activation and the inhibitory effects of $\mathrm{Ca}^{2}+$ ions and high $\mathrm{NaCl}$ concentrations. Differences between the amidolytic activities on tripeptide- $p$-nitroanilide substrates and different sensitivities towards serine protease inhibitors shows, however, that there are still some differences between the protein $\mathrm{C}$-activating proteases from the various Agkistrodon species. Such intra and subspecies variation of the structure and function of venom components are very typical for snakes belonging to the genus Agkistrodon. ${ }^{27}$

A major difference between the protein $\mathrm{C}$ activators from Agkistrodon balys balys and Agkistrodon contortrix contortrix was observed in studies of bovine protein $\mathrm{C}$ activation. In the case of the activator from Agkistrodon contortrix contortrix activation of both human and bovine protein $\mathrm{C}$ were strongly inhibited by $\mathrm{Ca}^{2+}$ ions and by high $\mathrm{NaCl}$ concentrations under our experimental conditions. Human protein $\mathrm{C}$ activation by the activator from Agkistrodon halys halys was also very sensitive to the presence of $\mathrm{Ca}^{2+}$ ions $\left(\mathrm{K}_{\mathrm{i}}=0.8 \mathrm{mM}\right)$ and to the $\mathrm{NaCl}$ concentration $\left(\mathrm{K}_{\mathrm{i}}=20\right.$ $\mathrm{mM}$ ). However, with bovine protein $\mathrm{C}$ much higher $\mathrm{CaCl}_{2}$ and $\mathrm{NaCl}$ concentrations are required in order to observe inhibition (cf. Figures 3 and 4). These observations indicate that there are considerable differences between human and bovine protein $\mathrm{C}$ on one hand and between the venom protein $\mathrm{C}$ activators on the other hand.

Orthner et al. ${ }^{15}$ advanced the hypothesis that $\mathrm{Ca}^{2+}$ ions and $\mathrm{NaCl}$ change the conformation of protein $\mathrm{C}$ in such a way that it becomes a less favourable substrate for the protein $\mathrm{C}$ activator. Considering the experiments reported in the present paper and pursuing the proposal of Orthner and coworkers results in a complex picture with different conformations for human and bovine protein $\mathrm{C}$ at high $\mathrm{Ca}^{2+}$ and $\mathrm{NaCl}$ that are recognized by one activator (Agkistrodon halys balys) and not by the other activator (Agkistrodon contortrix contortrix). It is, however, also possible that other effects contribute to the observed calcium and ionic strength dependence of venom-catalysed protein $\mathrm{C}$ activation. Strong effects of ionic strength on chemical reactions are often taken to implicate that ionic (electrostatic) forces play an essential role in the interactions between the reacting substances. In the case of protein $\mathrm{C}$ activation by the venom activators this would mean that ionic interactions between protein $\mathrm{C}$ and the venom activator may have an important contribution to the formation of the enzyme-substrate complex and the subsequent proteolysis. Considering the properties of protein $\mathrm{C}$ and the venom activators from the various Agkistrodon species this will likely be an ionic interaction between a negatively charged domain on protein $\mathrm{C}$ and a positively charged protein domain on the venom activator. Such an interaction will be prevented both at increased ionic strength and also by 
$\mathrm{Ca}^{2+}$ ions, since this will reduce the negative charge of protein $C$ by binding to the $\gamma$-carboxyglutamic acid residues. Depending on the net electrostatic charges of the protein domains involved in the interactions between protein $\mathrm{C}$ and the activator this may result in different $\mathrm{Ca}^{2+}$ ion and ionic strength effects on reactions between protein C's and venom activators from different species. In this respect it interesting to mention that there is a high degree of divergence in the amino acid sequences of human and bovine protein $\mathrm{C}$ around the peptide bond that is cleaved during protein $\mathrm{C}$ activation. ${ }^{28}$ It is obvious, however, that more detailed studies will be required to gain more insight in these differences between human and bovine protein $\mathrm{C}$.

Finally we would like to emphasize that it is of interest to study the functional properties of the protein C activators present in the venoms of other Agkistrodon species. Our experiments indicate that these protein C activators may exhibit a number of important functional differences. It is, therefore, possible that other Agkistrodon species contain a protein C activator whose activity on human protein $\mathrm{C}$ is not inhibited by $\mathrm{Ca}^{2+}$ ions and high $\mathrm{NaCl}$ concentrations. Such an activator will be the preferred enzyme in a diagnostic test for the quantitation of plasma protein $\mathrm{C}$.

Acknowledgements-This work was supported in part by a grant from the Committee Cooperation Eastern Europe of the Dutch Organization for Scientific Research (NWO).

\section{References}

1. Stenflo J. A new vitamin $\mathrm{K}$-dependent protein. Purification from bovine plasma and preliminary characterization. J Biol Chem 1976; 251: 355-363.

2. Kisiel W. Human plasma protein C: isolation, characterization, and mechanism of activation by $\alpha$-thrombin. J Clin Invest 1979; 64: 761-769.

3. Kisiel W, Canfield WM, Ericsson LH, Davie EW. Anticoagulant properties of bovine plasma protein $\mathrm{C}$ following activation by thrombin. Biochemistry 1977; 16: 5824-5831.

4. Walker FJ, Sexton PW, Esmon, CT. The inhibition of blood coagulation by activated protein $C$ through the selective inactivation of activated factor V. Biochim Biophys Acta 1979; 571: 333-342.

5. Vehar GA, Davie EW. Preparation and properties of bovine factor VIII. Biochemistry 1980; 19: 401-410.

6. Fulcher CA, Gardiner JE, Griffin JH, Zimmerman TS. Proteolytic inactivation of human factor VIII procoagulant protein by activated human protein $\mathrm{C}$ and its analogy with factor V. Blood 1984; 63: 486-489.

7. Fay PJ, Chavin SI, Schroeder D, Yuong FE, Marder VJ. Purification and characterization of a highly purified human factor VIII consisting of a single type of polypeptide chain. Proc Natl Acad Sci USA 1982; 79: 7200-7204.

8. Comp PC, Esmon CT. Generation of fibrinolytic activity by infusion of activated protein $\mathrm{C}$ into dogs. J Clin Invest 1981; 68: 1221-1228.

9. Esmon CT, Owen WG. Identification of an endothelial cell cofactor for thrombin-catalyzed activation of protein C. Proc Natl Acad Sci USA 1981; 78: 2249-2252.

10. Kisiel W, Ericsson LH, Davie EW. Proteolytic activation of protein C from bovine plasma. Biochemistry 1976; 16: 4893-4900.

11. Klein JD, Walker FJ. Purification of a protein C activator from the venom of the southern copperhead snake (Agkistrodon contortrix contortrix). Biochemistry 1986; 25: 4175-4179.

12. Stocker K, Fischer H, Meier J, Brogli M, Svendsen L. Characterization of the protein $\mathrm{C}$ activator from the venom of the southern copperhead (Agkistrodon contortrix contortrix) snake. Toxicon 1987; 25: 239-252.

13. Kisiel W, Kondo S, Smith KJ, McMullen BA, Smith LF. Characterization of a protein $\mathrm{C}$ activator from $\mathrm{Agkistro-}$ don contortrix contortrix venom. J Biol Chem 1987; 262: 12607-12613.

14. Kisiel W, Choi E, Kondo S. Isolation of a protein C activator from southern copperhead venom. Biochem Biophys Res Comm 1987; 143: 917-922.

15. Orthner C, Bhattacharya P, Strickland DK. Characterization of a protein $\mathrm{C}$ activator from the venom of $\mathrm{Agkis}$ trodon contortrix contortrix. Biochemistry 1988; 27: 2558-2564.

16. Exner T, Vaasjoki R. Characterization and some properties of the protein $\mathrm{C}$ activator from Agkistrodon contortrix contortrix venom. Thromb Haemostas 1988; 59: $40-44$.

17. Nakagaki T, Kazim AL, Kisiel W. Isolation and characterization of a protein $\mathrm{C}$ activator from tropical moccasin venom. Thromb Res 1990; 58: 593-602.

18. Strukova SM, Kogan AE, Tara A, Aaviksaar A. Anticoagulant effect of the protease from Agkistrodon venom mediated by protein $\mathrm{C}$ activation in rats. Thromb Res 1989; 55: 149-153.

19. Martinoli JL, Stocker K. Fast functional protein C assay using Protac, a novel protein $C$ activator. Thromb Res 1986; 43: 253-264.

20. McMullen BA, Fujikawa K, Kisiel W. Primary structure of a protein C activator from Agkistrodon contortrix contortrix venom. Biochemistry 1989; 28: 674-679.

21. Meier J, Adler C, Stocker K. The isoelectric focusing of Protac, the protein C activator from copperhead (Agkistrodon contortrix contortrix) venom: a note on experimental problems. Toxicon 1988; 26: 218-221.

22. Sadykov ES, Barabantshykova NA, Shuvalova I, Yukelson LY. The venom of snake Tchitomordnic Agkistrodon halys halys. V. Components with anticoagulant activity. Chim Prirodn Soed (Chem Nat Prod) 1985; 6: $851-852$.

23. Yukelson LY, Tans G, Thomassen MCLGD, Hemker $\mathrm{HC}$, Rosing J. Procoagulant activities in venoms from Central Asian snakes. Toxicol 1991; 29: 491-502.

24. Sala N, Owen WG, Collen D. A functional assay of protein C in human plasma. Blood 1984; 63: 671-675.

25. Laemmli UK. Cleavage of the structural proteins of the head of the bacteriophage T4. Nature (Lond) 1970; 227: 680-685. 
$\mathrm{Ca}^{2+}$ ions, since this will reduce the negative charge of protein $\mathrm{C}$ by binding to the $\gamma$-carboxyglutamic acid residues. Depending on the net electrostatic charges of the protein domains involved in the interactions between protein $\mathrm{C}$ and the activator this may result in different $\mathrm{Ca}^{2+}$ ion and ionic strength effects on reactions between protein C's and venom activators from different species. In this respect it interesting to mention that there is a high degree of divergence in the amino acid sequences of human and bovine protein $\mathrm{C}$ around the peptide bond that is cleaved during protein $C$ activation. ${ }^{28}$ It is obvious, however, that more detailed studies will be required to gain more insight in these differences between human and bovine protein $C$.

Finally we would like to emphasize that it is of interest to study the functional properties of the protein $C$ activators present in the venoms of other Agkistrodon species. Our experiments indicate that these protein $C$ activators may exhibit a number of important functional differences. It is, therefore, possible that other Agkistrodon species contain a protein $\mathrm{C}$ activator whose activity on human protein $\mathrm{C}$ is not inhibited by $\mathrm{Ca}^{2+}$ ions and high $\mathrm{NaCl}$ concentrations. Such an activator will be the preferred enzyme in a diagnostic test for the quantitation of plasma protein $C$.

Acknowledgements-This work was supported in part by a grant from the Committee Cooperation Eastern Europe of the Dutch Organization for Scientific Research (NWO).

\section{References}

1. Stenflo J. A new vitamin K-dependent protein. Purification from bovine plasma and preliminary characterization. J Biol Chem 1976; 251: 355-363.

2. Kisiel W. Human plasma protein C: isolation, characterization, and mechanism of activation by $\alpha$-thrombin.
$J$ Clin Invest $1979 ; 64: 761-769$.

3. Kisiel W, Canfield WM, Ericsson LH, Davie EW. Anticoagulant properties of bovine plasma protein C following activation by thrombin. Biocbemistry 1977; 16:

4. Walker FJ, Sexton PW, Esmon, CT. The inhibition of blood coagulation by activated protein $\mathrm{C}$ through the selective inactivation of activated factor V. Biochim Biophys Acta 1979; 571: 333-342.

5. Vehar GA, Davie EW. Preparation and properties of bovine factor VIII. Biochemistry 1980; 19: 401-410.

6. Fulcher CA, Gardiner JE, Griffin JH, Zimmerman TS Proteolytic inactivation of human factor VIII procoagulant protein by activated human protein $\mathrm{C}$ and its analogy with factor V. Blood 1984; 63: 486-489.

7. Fay PJ, Chavin SI, Schroeder D, Yuong FE, Marder VJ. Purification and characterization of a highly purified human factor VIII consisting of a single type of polypeptide chain. Proc Natl Acad Sci USA 1982; 79: 7200-7204

8. Comp PC, Esmon CT. Generation of fibrinolytic activity by infusion of activated protein C into dogs.

f Clin Invest 1981; 68: 1221-1228.

. Esmon CT, Owen WG. Identification of an endothelial cell cofactor for thrombin-catalyzed activation of protein C. Proc Natl Acad Sci USA 1981; 78: 2249-2252.

10. Kisiel W, Ericsson LH, Davie EW. Proteolytic activation of protein C from bovine plasma. Biochemistry 1976; 16:

11. Klein JD, Walker FJ. Purification of a protein C activator from the venom of the southern copperhead snake (Agkistrodon contortrix contortrix). Biochemistry 1986; 25: $4175-4179$.

12. Stocker K, Fischer H, Meier J, Brogli M, Svendsen L. Characterization of the protein $\mathrm{C}$ activator from the venom of the southern copperhead (Agkistrodon contortrix contortrix) snake. Toxicon 1987; 25: 239-252.

13. Kisiel W, Kondo S, Smith KJ, McMullen BA, Smith LF. Characterization of a protein C activator from Agkistrodon contortrix contortrix venom. J Biol Chem 1987; 262:

14. Kisiel W, Choi E, Kondo S. Isolation of a protein C activator from southern copperhead venom. Biochem Biophys Res Comm 1987; 143: 917-922.

15. Orthner C, Bhattacharya. P, Strickland DK. Characterization of a protein $\mathrm{C}$ activator from the venom of $\mathrm{Agkis}$ trodon contortrix contortrix. Biochemistry 1988; 27:
2558-2564.

16. Exner T, Vaasjoki R. Characterization and some properties of the protein $C$ activator from Agkistrodon contortrix contortrix venom. Thromb Haemostas 1988; 59:
40-44.

17. Nakagaki T, Kazim AL, Kisiel W. Isolation and characterization of a protein C activator from tropical moccasin venom. Thromb Res 1990; 58: 593-602.

18. Strukova SM, Kogan AE, Tara A, Aaviksaar A. Anticoagulant effect of the protease from Agkistrodon venom mediated by protein C activation in rats. Thromb Res 1989; 55: 149-153.

19. Martinoli JL, Stocker K. Fast functional protein $C$ assay using Protac, a novel protein C activator. Thromb Res 1986; 43: 253-264.

20. McMullen BA, Fujikawa K, Kisiel W. Primary structure of a protein $C$ activator from Agkistrodon contortrix contortrix venom. Biochemistry 1989; 28: 674-679.

21. Meier J, Adler C, Stocker K. The isoelectric focusing of Protac, the protein C activator from copperhead (Agkistrodon contortrix contortrix) venom: a note on experimental problems. Toxicon 1988; 26: 218-221.

22. Sadykov ES, Barabantshykova NA, Shuvalova I, Yukelson LY. The venom of snake Tchitomordnic Agkistrodon halys halys. V. Components with anticoagulant activity. Chim Prirodn Soed (Chem Nat Prod) 1985; 6:

23. Yukelson LY, Tans G, Thomassen MCLGD, Hemker HC, Rosing J. Procoagulant activities in venoms from Central Asian snakes. Toxicol 1991; 29: 491-502.

24. Sala N, Owen WG, Collen D. A functional assay of protein $\mathrm{C}$ in human plasma. Blood 1984; 63: 671-675.

25. Laemmli UK. Cleavage of the structural proteins of the head of the bacteriophage T4. Nature (Lond) 1970; 227:
$680-685$. 
H. M. Bakker et al.

26. Tans G, Janssen-Claessen T, Rosing J. Amidolytic detection of prothrombin activation products after SDS-gel electrophoresis. Thromb Haemostas 1989; 61: 386-391.

27. Chippaux J-P, Williams V, White J. Snake venom variability: methods of study, results and interpretation. Toxicon 1991; 29: 1279-1304.
28. Foster D, Davie EW. Characterization of a cDNA coding for human protein C. Proc Natl Acad Sci USA 1984; 81: 4766-4770.

29. Hemker HC. Handbook of synthetic substrates for the coagulation and fibrinolytic system. Boston: Martinus Nijhoff, 1983; 31 . 